\title{
Russian City Planning, Democratic Reform, and Privatization: Emerging Trends
}

\author{
Christopher Shove and Richard Anderson
}

\begin{abstract}
The emerging democratic and privatization reforms are shaping city planning practice in Russia. This paper provides a brief history of city planning, a typical schema of city governance, and describes some of the effects of democratic reform and privatization related to city planning. Also covered are general points about city planning education in Russia and a conclusion on probable city planning practice outcomes from the current societal context.
\end{abstract}

Christopher Shove, an assistant professor at the University of Oklahoma's regional and city and planning division, has been visiting and working in Russia for brief periods since 1991.

Richard Anderson, an associate professor at the University of Oklahoma's regional and city planning division, worked in Moscow and the Komi Republic in Russia in 1993 assisting in the planning of a new town.

\section{INTRODUCTION}

Russian cities that have remained so staid and untouched for centuries are now starting to change rapidly. This change is not just that which is blatantly evident in the signs and facades of fast food establishments along Moscow's Tverskaya (Gorki) Street, the ubiquitous kiosk vendors and Western chain stores, or the glittery new hotels that cater to Western businesses and are now nurturing a fledgling tourist industry. The change is that of the new market demands for added infrastructure, housing, and commercial and industrial space, which is profoundly altering the character of almost all Russian cities. This paper describes some of the current contextual issues associated with the privatization movement and emerging democratic reform that are increasingly affecting city planning practice in Russia. It also examines current local planning practice and the difficult charge that practitioners are now facing.

Russia is worthy of examination for several reasons. Most of the growth is concentrated in its many large cities. Under the Soviet Union, it assiduously pursued a national goal of town building. Also, Russia is as intellectually sophisticated as the United States and traditionally has had an advanced city planning practice. However, what is most remarkable is that Russian city planning practice is evolving from a stringently controlled social and economic system. It is going through a metamorphosis with the market and democracy acting as strong central catalysts.

In our terms, we can only wonder and try to visualize what our cities would look like if there were no private real estate market. In some measure, analyzing Russian cities and planning practice clarifies our own city planning system. Metaphorically, one could say that the characteristics of the color white become much clearer when contrasted with black. In comparing city planning practice in the United States with that of other countries, the effort is not to prove that one system is superior to the other but rather to point out differences and to learn from them.

Under the Soviet system, there were innumerable plans and planning activities, but much of this effort was viewed as ill-conceived and deleterious. Numerous vestiges of those plans and planning efforts still remain in place in Russia. Consequently, plans and plan-making are still viewed with scorn and contempt. In fact, this research was often hindered by the general disdain that most municipal officials had for any notion of planning. However, more probing soon revealed that these officials indeed were interested in using what we in the West call "planning." Therefore, for the purpose of clarification, the use of the term "planning" or "city planning" refers to what we in the United States think of as the components and scope of traditional city planning: comprehensive development plans (incorporating policy and physical issues related to typical elements of transportation, land use, 
demographics, economics, and infrastructure and facilities), and its related activities (such as goal-making, information gathering, citizen participation, planning processes, and implementation strategies). All other uses of the term planning have been qualified. For example, "centralized planning" refers to the overarching, national planning process in which plans emanating from various ministries had to be adhered to by regional and local planning agencies. Failure to comply with central planning mandates resulted in expulsion from the Communist Party, loss of employment, and most probably imprisonment. This action occurred so often by a seemingly random selection process that it was the foremost concern of all but the highest officials. So in this paper we have attempted to examine Russian city planning through the lens of our American city planning practice. In Russia's case, portions of this general practice have been affected by several different agencies in the same city. However, there are still general plans analogous to U.S. city comprehensive plans, and there are comparable city planning activities primarily conducted by each city's chief architect.

Much of this work is derived from personal interviews of key figures in local government associated with city planning. Types of officials interviewed generally included the following: governors or deputy governors of oblasts (states), mayors or deputy mayors, administrators (chief executive) of raions (counties), and chief architects who are principally responsible for city or regional planning. On some occasions it was possible to interview other functionaries such as the directors of property committees (individuals that process and assess requests for privatization); directors of Bureaus of Technical Inventory (specialists that are responsible for city land tenure records and titles); directors of Land Resource Committees (officials that are primarily concerned with the privatization of rural land, its use, and titling); city attorneys; directors of apartment privatization committees; and notaries. In Russia notaries are attorneys who verify and maintain records on all real estate sales contracts. Additionally, much anecdotal information was collected from various citizens, businessmen, academicians, and civil servants who had been exposed to city planning. The interviews occurred during different periods of 1992, 1993, and 1994.

The raions, cities and oblasts included in the study were visited during the course of four field projects in western or "European" Russia. ${ }^{1}$ In each project, it was essential to determine what constituted city planning practice and to identify the various influences that impinged upon it. The information gathered for this article was not fashioned from either a systematic sampling procedure or the application of a standardized interviewing instrument. Rather, it was collected episodically from dozens of people who had important roles in planning as well as many years of practice.

To clarify the context of current Russian city planning, it might be helpful to mention some of the more salient events in Russian urban development that have had significant impacts on city planning. Among those very early ones would be the continual invasions of cities by Mongolian hordes and others, which encouraged cities to fortify and develop in multiple rings or circular patterns. Common to most older Russian cities, with the exception of St. Petersburg, is the central Kremlin or citadel that served as both the seat of government and religious center. These are surrounded by high massive walls that provided protection for the populace in times of war, as well as insulation for the administration in times of acute civil unrest. Furthermore, when Russia began to open up to foreigners in the 1700 s, the Czar mandated that the non-Russians were to be kept in specified enclaves to limit their interaction with the populace. The Nemsti (German) quarter in Moscow evolved directly from this xenophobic policy (Massie 1980). This policy also resulted in nucleated settlements of particular ethnic groups along the periphery, such as the Kitaygorod district of Moscow, that were later subsumed in the growth of the city.

Contrary to the gradual evolutionary development process of most Russian cities, St. Petersburg emerged in 1712 as a new town at the edge of the Baltic Sea under the personal direction of Czar Peter the Great. Since Russia had neither engineers nor architects at the time, Peter chose to employ expatriates to build his city and so enlisted the help of many Dutch, French, and German engineers. The grand canals, splendid boulevards, and opulent buildings clearly reflect these 18th century western European influences.

Until the time of the revolution early in this century, the governance of cities was solidly within the purview of the czar. It was he or she who appointed and empowered the local nobility and the church to make laws and to govern. Regional princes allowed citizens of lessor nobility to administer the day-to-day operations of the city (Langer 1976). Due to the riots in Moscow in 1649, Czar Alexis Miklaiovich expanded the powers of local government and enhanced its right to handle municipal problems (Miller 1976). Later in 1699, Peter the Great augmented the autonomy of the local administrations, but doubled their taxes. However, in the 1800 s the Czars repealed many of the powers they had bestowed upon local governance (Hamm 1978). An important point to note from this long history of national control is the tight authority over city governance and development that held up until 1992.

\section{Soviet-Era City Planning}

It wasn't until the beginning of the 20th century, after the Communist Revolution of 1917, that Russian city building changed appreciably. The first official act in Russian city planning that occurred after the revolution was the promulgation of the Rules for the Planning and Building of Towns (Bliznakov 1976). Thereafter under Communism, a strong centralized process of city planning ushered in Russia's greatest era of city building. In the fifty years between 1926 and 1976, the Soviet Union built well over a thousand new towns with 
populations in the tens of thousands (U.S. Department of Housing and Urban Development 1976, 14). By 1989 there were 6,216 cities in the Soviet Union with 296 having populations in excess of 100,000 and 23 with populations over one million (Rowland 1992, 36).

Almost all of the new cities were built to provide labor to exploit resources or produce manufactured goods. These cities were akin to American and English "company towns." This can be seen in the plans of most "new towns" that appeared in the early Soviet five-year plans, particularly the lineal plan of Stalingrad (1940) and other industrial cities that were developed similarly to the early English and American mill towns such as Lowell, Mass. (Goodman 1947).

Under the Soviet system the Politburo, the nucleus of the Communist Party Central Committee established national goals. The goals were then elaborated by the Council of Ministers into operational objectives. The state planning agency, GOSPLAN, translated the objectives into specific directives for the government ministries to follow. City development directives were forwarded to GOSTROY, the State Committee on Construction Matters in the USSR, to implement. GOSTROY would then issue general plans to cities. However, it also operated as a consulting firm and used its research arm, the Central Research and Design Institute of Town Planning, to develop and institute urban design standards and development regulations. In many instances this unit would directly involve its staff of well over seven hundred in making plans for specific cities.

At the local level, most power was vested in the mayor or administrator who was either a member of the party or worked in close consultation with it. Members of local soviets (city councils) elected by the people in controlled elections gave local representation to municipal government. These bodies were quite large and in many instances had one-hundred to two-hundred members. Day-to-day operational matters of the city general plan rested with the chief architect, an appointed official of the city.

In most cities the general plan, developed and monitored by GOSTROY, was updated or modified by the chief architect every five years. It served as a general guide for municipal development and addressed a broad set of issues related to land use, transportation, and the location of necessary community facilities. It was the job of the chief architect to implement the plan in consultation with other local officials and possibly the local institute of architecture and city construction. The goals of the general plan were rigidly proscribed by state regulations issued by GOSTROY. Once completed, the updated or revised general plan was submitted to the oblast (state) chief architect who reviewed it for compliance to Soviet Union laws and requirements. The oblast chief architect would then submit the plan to the national echelon of GOSTROY for final approval. If approved, the updated general plan would then be implemented. However, it must be pointed out that in those times general plans for cities were secret documents. Thus, no attempts were made to garner local support for them because it was neither appropriate nor necessary. Planning was done for the city rather than with the city.

All in all there was little attention paid to any of the sociological aspects of urban development where planning was done. As Lappo characterizes it: "In Soviet urban planning it had been customary to consider cities as production centers and their inhabitants as labor resources. Social needs were constantly subservient to the needs of production. A consequence of this ordering of priorities was the social inferiority of Russian cities" (Lappo 1992, 530).

A final point concerning the Soviet era that affected city planning was the prohibition of free movement of the population. All Soviet citizens were required to secure the approval of the state before they could relocate. The basic tool for enforcing this restriction was the residency certificate (propiska). In order for a citizen to be legally employed or receive health care and other state benefits, he or she had to have this certificate cleared by the local police. The lack of the certificate, which verified residence, resulted in immediate arrest, expulsion from the city, or both.

\section{- Current Context of Russian City Planning}

Because of the abrupt changeover in government and national leadership, it is very difficult to identify and describe a "unified" context or environment in which city planning is practiced. However, some brief discussion of contextual elements might sharpen a few of the problem areas city planning is now facing. This paper will now proceed to discuss some of the more important ones.

\section{Government Structure of City Planning}

In Russia, the levels of government are the state (national); oblast, kray, or independent republic (units similar to U.S. states); and local governments of cities, raions (units similar to American counties), and towns and villages. Generally, local governments report to the oblast government which in turn reports to the state (national) government. The most notable exception to the hierarchical arrangement is the City of Moscow, which seems to demonstrate powers that at times surpass those of the national government. For example, it has successfully ignored national mandates to privatize real estate. Acting largely as a city-state, it has prevented any intervention of the national government (ministries, courts and so forth) into its local affairs (Moscow Times May 28, 1994, 11). In spite of this blatant example to the contrary, most cities adhere to the new laws and regulations of the oblast and state (national) governments.

The political structure of city government is slowly changing, but typically it still retains the offices of the mayor and numerous deputy mayors (normally around seven or eight) responsible for the administration of different municipal departments. One of the deputy mayors is regarded as the 


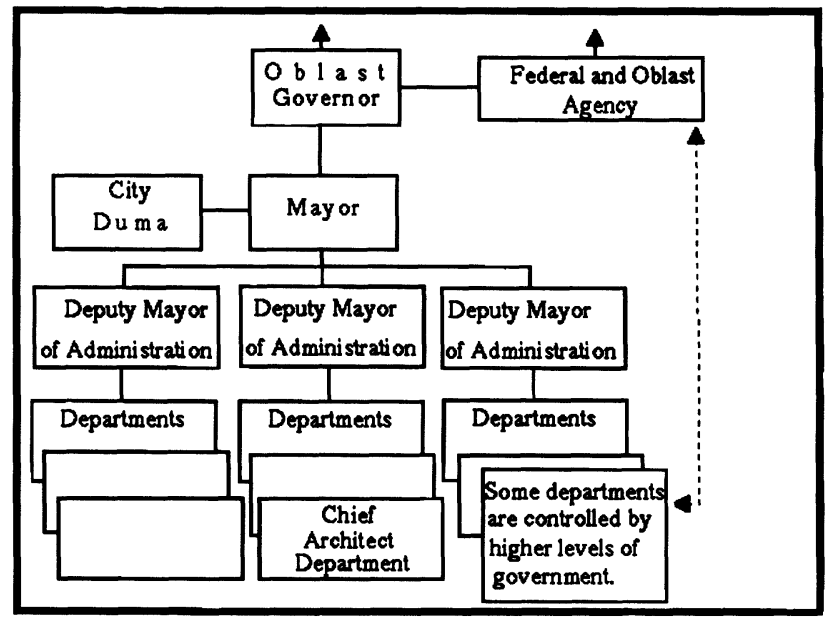

Figure 1. Typical and abbreviated Russian city government structure.

senior administrative functionary and holds the position of "vice-mayor." The central figure in city planning activity is the chief architect of the city.

The local political structure also includes an elected city council, the duma, that has replaced the former local soviets. Members are affiliated with different parties and are elected from particular wards of the city. Even though the duma has the authority to establish local ordinances, the mayors frequently issue special decrees that supersede them. The Russian system of local government differs substantially from the American one in that the mayor is usually appointed by the governor of the oblast (state) who, in turn, is appointed by the president of Russia. Only in a few cities is the mayor popularly elected (Moiseyev 1994). In the case of political appointments, the mayor of course is a very powerful individual. The net result of this situation is that the approval of the mayor is key to the effectuation of any planning policy. In many cities it is the mayor who currently mandates city planning practices and municipal regulations (e.g., city ordinances, permit approvals, land use changes, etc.). A typical generalized table of organization of local government appears in Figure 1.

As it can be noted in Figure 1, the chief architect works within a department directly under a deputy mayor. (Both the particular department and deputy mayor can vary from city to city.) In 'practice, however, architects are still responsible to the mayor who appointed them. This is a very different scenario from that of the Soviet era, when the terms of appointment of the chief architects extended well beyond those of most mayors. Now there is usually a turnover of the chief architects whenever a new mayor is elected or appointed (Borisov 1994).

\section{City Planners and City Planning Departments}

Currently the chief architects are responsible for leading the city planning activity and implementing its policies. However, these planners still must work within the city's political and bureaucratic framework. Furthermore, they must be responsive to two major interests external to city government: (1) the large industrial enterprises that control significant amounts of urban infrastructure such as streets, schools, health facilities, and so forth, and (2) private development interests held by individual citizens or other entities that are currently developing their own real estate.

Chief architects are employees of city government. Typically they hold a degree in architecture from one of many institutes offering training in architecture, town construction, or civil engineering. Chief architects have strong design skills (in the visual and functional sense), but maintain little background in understanding the critical social processes of urban development. This is an important point to underscore because as cities begin to function autonomously, their leaders must now make planning (policy as well as design) decisions that were formerly passed down from higher ranking officials in state and national ministries.

The organization of the chief architect's office is generally dependent upon the size of the city. In a city of more than 100,000 inhabitants the office may include a general plan division, an engineering division, and a building regulations division. In some cases the chief architect's office may have a survey and mapping division.

\section{Reform Issues}

The reform movement in Russia covers many areas of key national interest. One only trivializes it in thinking of it as solely market reform. In regards to the city, the reform movement is made manifest in numerous ways. Among those areas at the top of the list are such things as the demise of the Soviet legal system and the construction of an entirely new one. Next would be the privatization of real estate and industries with their full complement of social services such as hospitals, housing, security, and schools; the unprecedented accretion of individual civil liberties and personal rights; the elimination of centralized planning; the reconstruction of local government and the wholesale discard of entire branches of government (ministries, bureaucracies, etc.); and the emergence of private consortia and corporations to replace nationalized public industry.

It is much too early to identify clear trends in Russian city planning; only issues and knotty problems are apparent. These are what comprise the new context of city planning in which practitioners must operate. While most cities are experiencing the impacts of these issues, no common mandates or responses can readily be observed. For the most part, cities are almost wholly involved in all aspects of "current planning." This dayto-day activities of plan review (permit processing, inspections, reviewing privatization applications, and so forth) consume the time and resources of the chief architect's office. Some cities have stronger or weaker ties to the older communist power structures, causing additional layers of confusion and consternation in the planning arena. Others face a variety of eco- 
nomic crises, including revenue shortfalls, appallingly low wages for essential service workers (police, firemen, etc.), and, at times, the influences of organized crime figures. The most important trend, though, is the speed and force of the reform movement at the local level. Therefore, while almost all cities are experiencing the impacts of new issues vis-à-vis their own local economies and the lack of a viable national or state legislative framework in which to operate, almost all cities seem to be developing their own tailored city planning practices for organization and assignment of duties to planning personnel, development of planning regulations, establishment of appeal procedures, and so forth.

\section{Legal Issues}

The legal basis of current city planning in Russia is influenced by old Soviet law and practices; new Russian law and legal practices; and, more importantly, the practical realities or consequences of reform. There are now a few new city planning laws that address some of the current issues, but they are generic and slow in implementation (Shaw 1992). From a purely legal viewpoint almost all Soviet-era laws and subsequent regulations are unenforceable now that a new Russian constitution preempts the older one. However, due to sheer bureaucratic momentum and a lack of viable new laws, many of the Soviet-era laws and regulations pertaining to city planning are still followed for lack of anything better or more useful (Rachkovsky 1994, Borisov 1994).

\section{Privatization Issues}

Privatization actually includes several separate and distinct reforms, each of which generates its own impact on city planning practice. The broadest categories of the movement include the privatization of (1) commercial and industrial enterprises and (2) real estate. Both have manifested their own subset of impacts on city planning.

\section{Privatization of Commercial and Industrial Enterprises}

The privatization of enterprises has had three impacts that have strongly affected city planning and urban development. First, it has directly involved city-level government through the formation of what are currently referred to as property committees or municipal property committees. These bodies are responsible for processing the applications submitted by various entities requesting to privatize. The most difficult part of the job that these committees are now facing, which in turn has affected city planning most severely, has been identifying the types of enterprises that should be allowed to privatize and then delimiting the real property allocated to them. For example, if a downtown business is privatized, should its owners be given a deed or title to the land it occupies? When this question arises in a proposed privatization case in Moscow, there is an immediate concern that the municipality will lose control of the land that the enterprise occupies. When key community facilities apply for privatization, the issue can become even more complicated. For example, should a hospital choose to privatize, the public could conceivably lose health care services in that sector of the city. Thus, these issues have repercussions and ripple effects that are linked to any number of city planning decisions or even chains of decisions.

A second important impact of privatization centers on the "social sphere" that an enterprise encompasses. Under the Soviet system, the "social sphere" of activities that industrial enterprises maintained was far reaching. Many had their own schools, health clinics, hospitals, housing areas, parks, and farms as well as recreation and retirement programs (Shomina 1992). In the mid-1980s the ferrous metallurgy industries alone owned 226 hospitals, 84 spa and mud-bath resorts, 413 clubs and cinemas, 474 libraries, 111 museums, 164 stadia, 80 swimming pools, and 238 gymnasiums (Shomina 1992, 224). Further, toward the end of the Soviet-era, industrial and commercial enterprises owned half of all urban housing, and accounted for approximately 50 percent of the funds invested for schools and hospitals (Shomina 1992). Under privatization, enterprises cannot afford to fund and operate these extensive arrays of social institutions and benefits, so they jettison them. Many enterprises have simply transferred these former responsibilities onto local governments, which have few if any resources to continue them.

The third impact of privatization concerns the large parcels of land that were allocated to industrial enterprises under the Soviet system. Many of these tracts have great potential value for the enterprises as substantial pieces of collateral for development and expansion. Some oblast governments, through legislation, have removed these lands from their municipal land banks and returned them to the enterprises (Sadovnikova 1994). They thus can become "uncontrolled territories" within the cities that can be sold, subdivided, and developed without any benefit of city planning. Added to this adversity is the acute lack of public information on these large tracts; the centralized operation of Soviet industries was highly secretive. Many of the enterprises still are very closed-mouthed about their operations, and there are no laws requiring them to do otherwise. Thus, municipal governments have virtually no data regarding environmental conditions, current land uses, or other development aspects of these lands.

\section{Privatization of Real Estate}

The privatization of real estate has been problematic for city planning as well, with two major impacts. The first has centered on the privatization of apartments for their occupants. In general, Russian citizens who were registered as occupants of particular dwellings before 1991 could apply for the ownership of them; as expected, most did. However, 
this arrangement still left in question the ownership of common areas of the large residential blocks. This putative privatization effort left not only the small matters of building lobbies, hallways, elevators, and stairwells unaccounted for on the register of private property, but also the numerous parks and playgrounds that were integral parts of the high-rise apartment complexes. Were these areas de facto common property of all the new owners, or were they still municipal properties? How were they to be regarded when it came to maintenance responsibilities? Currently national model condominium legislation is under review to solve this problem of collective ownership. However, many cities are now attempting to fashion such laws. Again, it is one more publicprivate matter for the chief architects to adjudicate. Considering that most apartment complexes are high-density super blocks with thousands of inhabitants, this is not a trivial problem.

The second aspect of real estate privatization that greatly affects city planning deals with unoccupied and unimproved urban land. By presidential decree in 1992, most land was to be allowed to be privatized. Under the previous Soviet system, a majority of citizens were allocated half-acre garden plots. This movement was instituted to encourage subsistence agriculture similar to the U.S. "victory gardens" of World War II. The assigned land could be cultivated, but building permanent structures was strictly prohibited. With the new national land policy now in effect, these garden plots are now being developed by their former stewards. Temporary summer homes or dachas are now being replaced by permanent singlefamily detached dwellings, even though the areas are wholly lacking in municipal infrastructure and services. This has caused an inordinate number of problems (health and otherwise) for both chief architects and local governments that are mandated to provide services. Most of these new developments are in the outskirts of the large cities.

In general, the privatization process has forced city planning practice to be largely reactive, addressing immediate urban concerns rather than the long-range issues of future development. Compounding the problem, of course, has been the dearth of new and current land use ordinances and regulations required to control rapid urban development.

Another impact of privatization associated with real estate that has been troublesome for planning and local governments in general is that of designated authority in planning matters. Who is to be in charge of city planning and safeguarding public welfare? Historically, the charge of city planning has been delegated through the hierarchy of central ministries to the chief architects and their bureaucracies. These individuals subsequently developed and implemented plans and design policies in close cooperation with their mayors and other central administrative figures. However, that too has changed. By presidential decree in 1992 a new ministry called ROSCOMZEN was created to accelerate land privatization and monitor its progress. This national ministry has regional and local offices in all of the oblasts, cities, and raions (counties). In some places the local COMZEMs (Committee on Land Resources and Use) consider it their responsibility to do land use planning, much to the outrage of the local chief architects. In the best situations there is tense cooperation; in the worst the chief architects do their utmost to undermine these local offices. Since the chief architect's office is part of local government and COMZEM a branch of the national or oblast government, there is often a division of political territory where the former operates within the city limits and the latter outside where the raions (county governments) are very weak.

Another related problem centers on the selection of the proper agency to record the ownership rights of real estate: a city department or the COMZEM? Since 1921, the city department called the Bureau of Technical Inventory (BTI) has recorded the legal rights for the use of real estate, which more recently has become the rights of ownership (Metyolkina 1994). (In 1921, to prevent the resurgence of the aristocracy and capitalists Lenin ordered the destruction of all real estate ownership records.) Since 1992, COMZEMs have been given presidential authority to record use and ownership rights. In most cases there is a governmental territorial division of responsibility where the BTIs record real estate within the city and COMZEMs record real estate outside of the city. However, in the rural areas the BTIs are recording real estate information even though the COMZEM is doing the same thing. At this time, it appears that the BTI records have a higher legal standing (Bochkanova 1994) because the courts adjudicate property disputes using BTI records. Furthermore, these records are the official source that the tax ministry uses to collect real estate taxes (Vidyultsev 1994). Interestingly, the clearest and most authoritative information for real estate can be found in the notary offices, many of which are private (Anyev, Samoilov 1994). Notary records clarify much of the confusion in regard to ownership. In Russia, real estate sales contracts must be notarized, so notaries keep records on all types of real estate transactions even if such transactions are not recorded by either the BTI or the COMZEM.

\section{Citizen Involvement}

Seventy years of near terror with the KGB has tended to make the average Russian fairly docile toward political bosses. That is changing. Citizens are starting to gain confidence in democracy and are slowly becoming more vocal in issues where government touches their lives. Thus, the voice of the public has put increased demands on the chief architects to meet with their constituents, hear their complaints, provide them information, and respond to their requests. While this is routine in the United States, it is a very new experience for most Russians. Furthermore, with real estate privatization making rapid progress, citizens are interacting more and more with local governments, meeting with administrators, securing building permits, requesting inspections, and so forth. In general, the chief architect's office has now become the 
clearinghouse or sounding board for almost all citizen complaints, and it is now easily identified by the long lines of individuals waiting (or acting) to resolve yet another set of problems.

\section{- EMERging Trends}

The following trends can be considered seminal regarding city planning and urban development. Change is abrupt, fast paced, pervasive, and accelerating, and that is the milieu in which city planning must operate. With virtually no legal framework to guide them, the chief architects have to become extremely innovative.

\section{Changing Urban Form}

The collapse of centralized planning and housing and the loosening of rigid controls have tended to generate substandard development (e.g., kiosks, car garages, neo-suburbs with no infrastructure). Suburbs and the impromptu commercial centers in central city neighborhoods have grown erratically. In general there has never been a spread of low-density suburban development along the periphery of Russian cities. In the past, land use along their perimeter was devoted to high-rise housing projects. At the corporate limits, land use changed abruptly to agricultural or village use. This kept overall urban densities very high and created a dramatic change in scale, image, and activity at the immediate outskirts of cities. Typically, an exurban settlement or village is very small, has no central water or sewerage system, and is largely lacking in paved streets, parks, or other community facilities.

However, since 1993 noticeable suburban development is beginning as individuals and contractors build housing. Many of these new developments are indeed starting to resemble American suburbia. Unfortunately, the local governments have not been able to control this new phenomenon very effectively. A major impediment to control of this peripheral growth has been the absence of an enforceable and effective code system to guide land subdivision. With no current statute available, cities tend to follow Soviet-era development codes, which do not include suburban development. Compounding the problem of uncontrolled suburban growth, many citizens now circumvent the red tape of the local authorities and build without permits. These two sets of circumstances have created a third major problem for the chief architects: meeting the demand for infrastructure and services required in these new areas. Site visits to many of these fledgling suburban areas found haphazard development, absence of infrastructure, and worse. Frequently, for example, the waste from one house flowed directly into the water well of another. Chief architects of some cities indicated that their municipalities might consider assessing impact fees to defray the cost of necessary infrastructure for these areas.

Besides suburbanization, city centers are undergoing noticeable change. High density low-rise older housing was very common in central cities prior to the collapse of the
Soviet Union. However, since then and especially since 1994, various Russian and other western companies have been buying-out or trading-out downtown housing for central commercial space. In many cities a common form of highdensity housing is the communal apartment building where several families share ownership of a unit. Many of these communal apartments date from the Stalin era and are both large and overcrowded. Most of the residents in them would like to leave and secure their own residential space, but cannot do so due to the negligible housing inventory. Thus, even if a Russian family sold its apartment at a substantial profit, there would be virtually be no place to move to. Consequently, many entrepreneurs buy up apartments on the urban perimeter for trade with central city residents who are in desperate need of single-family housing. Since the newer units on the outskirts are for single family occupancy, most central city families take the offer and move out. Once their older apartments units are remodeled, new commercial tenants move in. An extra benefit for new commercial tenants (especially if they are Russian) is that businesses in old residential shells are far less conspicuous from the street. This reduces their likelihood of having to pay "protection money" to organized crime syndicates whose activities have yet to be curbed. In any event the expansion of the commercial core in most Russian cities is gradually changing them, making them appear more like their western counterparts.

Besides the obvious need for more infrastructure to meet the demands of this new development there is the location, size, and adaptability of the existing systems to consider. Soviet cities were designed very tightly and relied heavily on rapid transit and other fixed transport systems to move people and goods. Now however, the new spatial shift of land use has made the fixed transport systems well out of alignment with the new urban form. This shift and the increasing numbers of cars per capita have created levels of traffic congestion and grid lock that were never seen before 1992 .

The city planning response to this rapid shift in urban form has ranged all the way from moratoria on all development to policies of benign neglect. However, there are chief architects who are trying new approaches. Some have attempted to control development through what they feel are logical land use codes, even though they do not have constitutional authority to enforce them. Others have used their influence with mayors and higher level appointed officials to withhold permits and schedule the extension of infrastructure. Those chief architects that are in good stead with their mayors have been most effective in channeling development. Russian city mayors are powerful figures who can shield their chief architects from an appreciable amount of potential adversity and possible litigation.

\section{Urban Governance}

Most Russian city government structures resemble the strong mayor form of government found in some American 
cities, but with one significant difference. The mayor is most often an officer appointed by the oblast (state) governor. Thus, the political loyalty of the mayor closely follows the wishes of this benefactor. However, since 1993 some cities have moved away from this model to locally elected mayors. Despite some difficulty in instituting this change, it appears to be catching on in more and more cities. In the raions, however, the chief administrators are appointed by the oblast governors, or by the mayors if their raion happens to be within the city limits.

The new election system has also changed the civil service system. Many of the new mayors now have the option of selecting and appointing their own key officials, including chief architects. This has of course brought about some major changes in many local administrations.

The other significant change that appears to be permanent is the replacement of the old city soviets (municipal councils) with city dumas. The older bodies were very large; many cities had municipal soviets of well over a hundred members. They were supposedly comprised of popularly elected candidates, but in point of fact this was hardly the case. In most instances the public was notified that there was only one candidate available for a particular position and that he or she was the one to vote for. Since 1993, with the disintegration of much of the power of the Communist Party, there has been much less coercion in these elections. The new dumas have far fewer members - usually five to twenty-depending on the size of the city. Also the members now represent particular wards or districts of their cities so they have to be more responsible to the wishes of their constituents.

\section{City Planning Practice}

There has been a noticeably significant change in city planning since the demise of the Communist Party and the Soviet era. In the earlier Soviet times, city planning practice could be characterized as the strict execution of urban development plans issued by the central planning ministry in Moscow. The chief architect's role was primarily that of an overseer insuring that the plans were implemented. While some chief architects were able to influence their city's development by making modest alterations in the particular orders issued to them, most executed these edicts to the letter. For the past few years, the workings of local government have replaced the operation of the older centralized planning system. Government and market reform have brought forth considerable local control over planning problems and issues. National-level city planning authorities still distribute proposed designs, model codes, and other related items to the chief architects, but they are generally ignored or taken as hardly more than suggestions.

While chief architects have gained more influence, they are not using it uniformly. Some still operate as they did in the Soviet era, while others have adopted practices that one might see in American cities where the operations of city planners and managers are closely coordinated. Some of the new entrepreneurs or developers view chief architects as political tyrants who hold a very proprietary attitude toward the operation of their kingdoms. Others are viewed in a diametrically opposite way, and consequently have been highly susceptible to external influence and, at times, corruption. On the other hand, still others take great pride in their cities and execute the duties of their office with diligence and dedication to orthodox planning practice.

Beyond these generalizations, specific emerging city planning practices include a concern for new subdivision regulations and general land use ordinances such as zoning, performance codes, and so forth. Prior land use development often resembled a planned unit development scheme. Now, with more single-family dwellings clustered in "neighborhoods," Russian city planners are attempting to establish alternative land use and development guidelines. For example, the draft Russian urban planning code is partially based on Western land use code concepts (Borisov 1994). At this time the strongest control of land use centers in the chief architects' approval authority over building permits. Second to this is the ability to influence the mayor to accept land development ordinances that insure health, safety, and general welfare.

Added public involvement has now made city planning a local activity. The new Russian constitution requires public notice for many local government actions. When asked, many chief architects stated they were well aware of this requirement, and that their offices operated in strict compliance with it. However, none stated that they took any affirmative measures to solicit public opinion or participation, but that they did consider the public viewpoint whenever local citizens chose to enter the city planning arena and express their ideas.

Chief architects are also practicing more comprehensive city planning. In the Soviet era, they were never involved in policy formation for housing, the operation of the local economy, or environmental issues. But now all of these matters have been thrust upon them, and they are beginning to plan in a much more inclusive manner. Unfortunately though, most of them only have technical (engineering, architectural, or urban design) training and lack the sociological and economic background needed to do true comprehensive planning.

Another aspect of city planning practice that is beginning to emerge in Russian cities is planning management. With increased autonomy there has followed a spate of new management responsibilities. In the Soviet era of central control, most planners were mere "plan checkers." Today however, they are plan-makers in a much more holistic sense and are responsible for the implementation of their ideas.

\section{City Planning Education}

There is no formal city planning degree in Russia. Traditionally, a chief architect attended a school of architecture and received training in urban design. However, even this was more as a study of multiple architecture (e.g., the aesthetic 
composition of a group of buildings or a spatial arrangement of activities) than an exploration of public context (cognitive mapping) or attitude surveys regarding parts or particular areas of a city. In general, the chief architects lament the paucity of training they were able to receive in social sciences in their architectural education. Those chief architects and consultants who have visited planning offices in the West have pointed to the critical need for training in economics, demography, ecology, law, management, public finance, administration, and government (Borisov 1994, Glazychev 1994).

Discussions with deans and faculties of architectural institutes indicate that they are acutely aware of the need to enhance city planning education. Most programs offering a professional degree in architecture require five years of study beyond a secondary education. Training demands a solid grounding in fine arts, as well as engineering, mathematics, and basic sciences. Some institutes offer a nonprofessional (four-year) degree that can be followed by a two-year master of architecture degree. Study at the master's level covers advanced design and requires the successful completion of a large independent project or a thesis. Many students work in international design competitions involving highly complex urban design problems and issues. On the face of it, this is much like the work found in an advanced American architectural curriculum. However, curricula in Russia differ substantially in that they are extremely rigid with few electives.

Since architecture is viewed as a technical field, most programs have been established in design institutes and technical schools rather than in universities. This physical isolation from allied fields has made it difficult to infuse programs with courses in humanities and the social sciences. Many faculty see the need for instituting specialized city planning curricula, but few are prepared to implement such changes in their architectural programs. Most did not have the faculty expertise to offer planning courses, and few, if any, had the resources to hire additional faculty (Nikolsky 1994). In one case a school received a grant of several computers with GIS software, yet none of the faculty were trained to use it. With rising inflation and devaluation of the ruble, many faculty skilled in computer technology and other vital areas of city planning have left academia for work in private industry.

Participation in an independent Master of Architecture project during the summer of 1993 for the relocation of small rural community revealed a great mastering of design skills and presentation techniques. Aside from being exquisitely displayed, the project was well supported by an inordinate amount of well organized data. Several boards were devoted to site analyses that included features of landscape, geophysical elements, and ecology, as well as the spatial arrangements of buildings and related infrastructure.

While there perhaps has been some contribution to general planning knowledge from schools other than architectural institutes, very little of it has become manifest in either the planning of cities or the solving of their pressing urban problems. In a few isolated cases such as in Nizhni Novgorod, there is an interest in developing a city public policy or specialized urban management program. It has only been within the last year or two that public policy programs have been based on market economies. In 1995 several donor entities like the U.S. Agency for International Development had begun to fund curricula such as these.

\section{- Concluding Observations}

Market and democratic reforms in Russia have had a tremendous impact on city planning practice. They have generated an overwhelming demand for market-oriented city planning knowledge and expertise. In the field there is an immediate need for city planning as cities expand and redevelop to accommodate the market changes required in their new economies. It is doubtful that there will be a sufficient transfer of such knowledge in the next few years to accommodate this change. Only in 1995 did the U.S. Agency for International Development begin a formal technical assistance program for urban planning practice. At that time city planning knowledge was of practical importance because local governments were refusing to privatize land to encourage a free market for real estate. Most city governments held off on privatization because they lacked codes, regulations, and other necessary ordinances to control development and thus insure the health, safety, and welfare of their citizens.

The dearth of planning knowledge related to private markets may lead to several consequences. As previously mentioned, city governments are slowing down the privatization process for real estate or, in some instances, have even halted it. The rapid increase in business activity will continue to spawn a constant demand for more and more commercial and industrial space. Simultaneously, municipalities will do their utmost to retain control of land and keep it off the market. As an intermediate solution they will probably offer short-term land use leases to corporations and entrepreneurs in the private sector. Many have already started using this strategy.

A second consequence will probably be increased public health problems. The chronic lack of infrastructure could lead to air and ground water pollution, traffic congestion, overcrowding, and general urban blight. Unauthorized and uncontrolled urban development will contribute substantially to continued environmental degradation and will severely reduce the quality of life on the outskirts of many cities. Also the lack of well-defined development approval procedures and chains of authority might lead to added municipal corruption as entrepreneurs circumvent the system and bribe functionaries to acquire needed approvals.

However, there is a positive side. In general the urban form and interior patterning of Russian cities is strikingly similar to the currently popular planning concepts of "new urbanism": walking scale; curvilinear streets; defined neighborhoods with their own shops, retail services, restaurants, etc.; an 
extensive park system; pedestrian spaces; uniform highly stylistic architecture; and so forth. With tight land control (municipal ownership) and stringent preservation codes for historic buildings, it might be very possible for the mayors and chief architects to lead new development in such a way that it will contribute to the livability and beauty of their cities. Some evidence of this can already be seen in Moscow, where Mayor Luzhkov orchestrated a massive, successful revitalization effort and has since received a citizen approval rating of close to 70 percent (Economist 1996, 40-41).

\section{NoTES}

1. The four projects were as follows. The first project was funded by a private firm to Chris Shove of the University of Oklahoma to develop a prototype real estate geographic information system for Moscow during the summer of 1992. The second project was funded by a Russian power generation firm and the Institute of the U.S.A. and Canada Studies of the Russian Academy of Sciences. The charge was to select a site in the Komi Republic and develop a preliminary master plan for a new town based on freemarket principles. The project occurred from 1992 through 1993. The third project, which took place in 1993, was funded by a city in northern Russia to develop an urban geographic information system. A fourth one was funded by the U.S. government to a private consulting firm to establish a model land titling system for twenty cities in Russia. This project lasted from 1994 to 1996. In each project it was essential to determine city planning practices and to identify the various influences on the development of Russian cities.

\section{REFERENCES}

Akifiev, L. 1994. Interview. City Chief Engineer, Kremlin, Nizhni Novgorod, Russia. August 25, 1994.

Anyev, Vitaly. 1994. Interview. Director, Nizhni Novgorod Notary Chamber. Tel. 8312-34-32-75. 17b Nizhne-Vozhskaya nab, Nizhni Novgorod, Russia. September.

Bater, J. 1977. Soviet town planning: Theory and practice in the 1970s. Progress in Human Geography 1:177-207.

Bater, J. 1980. The Soviet City. Beverly Hills, CA: Sage Publications.

Bliznakov, M. 1976. Urban planning in the USSR: Integrative theories. In The City in Russian History. Lexington: University of Kentucky Press.

Bochkanova, Olga. 1994. Interview. Head, City Legal Department. Tel. 8312-39-18-01. Kremlin, Nizhni Novgorod, Russia. August 15.

Borisov, Valeri. 1994. Interview. Director, City Building Department, Russian Federation Ministry of Construction, Moscow, Russia. Tel. 7095-939-0035. November.

Borokov, Sergei. 1994. Interviews. Assistant to the Mayor. Tel. 8312-33-4396. Kremlin, Nizhni Novgorod, Russia. July-October.

Brower, D.R., 1990. The Russian City between Tradition and Modernity, 1850-1900. Berkeley: University of California Press.

Dogadin, Evgeney. 1994. Director, Vladimir City Local Privatization Center. Vladimir, Russia. Interview in May and November 1994.

Economist. 1996. Russia: two proud cities. April 20: 40-41.

Evsyukov, Gregori. 1994. Interview. Director, City Bureau of Technical Inventory, City of Nizhni Novgorod, Russia. July 22.
Glazychev, Vyacheslav. 1994. Interview. President, Academy of the Urban Environment. Krymsky val. 8, Moscow, Russia 117049. May.

Goodman, P. and P. Goodman. 1947. Communitas. New York: Vintage Books of Random House.

Guzeeva, Elena. 1994. Interview. Director, Apartment Privatization Committee, City of Vladimir. Tel. 09222-3-15-64. November 1.

Hamm, M., ed. 1976. The City in Russian History. Lexington: University of Kentucky Press.

Khantonov, Alexander E. 1994. Interview. Chief Architect, City of Nizhni Novgorod. Kremlin, Nizhni Novgorod. July 26.

Langer, L.N. 1976. The Medieval Russian town. In The City in Russian History, ed. M. Hamm. Lexington: University of Kentucky Press.

Lappo, G.M. 1992. Urban policy in Russia: A geographic perspective. PostSoviet Geography 33:516-532.

Makov, Sergei. 1994. Interviews. First Deputy Mayor, Nizhni Novgorod. Tel. 8312-39-12-24. Kremlin, Nizhni Novgorod, Russia. AugustOctober.

Massie, S. 1980. Land of the Firebird: The Beauty of Old Russia. Blue Hill, ME: HeartTree Press.

Metyolkina, Nadia. 1994. Interviews. Head, Bureau of Technical Inventory, City of Vladimir. May and November.

Miller, D.H. 1976. State and city in seventeenth-century Muscovy. In The City in Russian History, ed. M. Hamm. Lexington: University of Kentucky Press.

Moiseyev, Valeri. 1994. Interview. Chief Administrator, Sormovsky Raion, 160, Komintern Str. Nizhni Novgorod, Russia. Tel. 7-8-312-334556. September.

Moscow Times. 1994. City bans private ownership of land. May 27:1.

Moscow Times. 1994. Chubais threatens Luzhkov with court. May 28: 11.

Nikolsky, E.K. 1994. Interview. Dean, Nizhni Novgorod Institute of Architecture and Civil Engineering. 1994. 603600 Ilyinskaya, 65, Nizhni Novgorod, Russia. October

Pichugin, Vladimir. Interview. 1994. City Chief Architect. Tel. 09222-2-7595. Vladimir, Russia. May 17.

Rachkovsky, Valeri. 1993-94. Interviews. City Chief Architect. Fax 82122-202-61, Syktivkar, Komi Republic, Russia. January \& June 1993, July 1994.

Rowland, R. 1992. Urban settlement size trends in the former Soviet Union. Post-Soviet Geography 33:34-48.

Ruble, B.A. 1992. Reshaping the city: The politics of property in a provincial Russian city. Urban Anthropology 21:203-233.

Rumiantsev, Igor. 1994. Interviews. Ecology Department, City of Kaliningrad. Tel. 095-511-2217. May.

Rumyantsev, Yury. 1994. Interview in Moscow. Deputy Mayor and Director, Department of Economy. Tel. 8312-39-11-24. Kremlin, Council Hall, Nizhni Novgorod, Russia 603082. October.

Russian Federation Ministry of Construction, 1994. City Code of the Russian Federation (draft). Moscow.

Sadovnikova, Nadejda. 1994. Interview. President of the Board, Vladimir Regional State Property Fund, Vladimir, Russia. Tel. 092-22-2-5137. May 16.

Samoilov, Sergei, H. 1994. Interview. General Manger, Moscow Notary Chamber. Tel. 7-095-923-8676. October.

Scornikov, Ganadi. 1994. Interviews. Chairman, Suzdal Raion Committee on Land Resources. Suzdal Raion Administration Building, Suzdal, Russia. May 18, November 4.

Serikov, Alexander. 1994. Interview. Deputy Administrator, Nizigorodsogo raion. Tel. 8312-33-45-56. Building 1, Puskunovan UL., Nizhni Novgorod, Russia 603005. August. 